\title{
Antigen capture ELISA for the heat shock protein (hsp60) of Chlamydia trachomatis
}

\begin{abstract}
Aims-To develop an indirect ELISA using the heat shock protein (hsp60) of Chlamydia trachomatis as antigen.

Methods-The hsp60 gene was amplified by PCR, expressed in the vector pDEV-107 and transformed into Escherichia coli. The recombinant protein, expressed as a $\beta$-galactosidase fusion product, was captured onto a solid phase using a monoclonal antibody directed against $\beta$-galactosidase. Following incubation with goat anti-human antibody conjugated to peroxidase and colour development on addition of peroxidase substrate, antibody recognition of antigen was quantified by optical density at $492 \mathrm{~nm}$.

Results-A sensitive and relatively specific ELISA to detect hsp60 has been produced, which can be exploited to determine the antibody response to $C$ trachomatis hsp60.

Conclusions-This assay will permit the future investigation of the immunopathogenesis of persistent inflammation following $\boldsymbol{C}$ trachomatis infection.

(F Clin Pathol 1996;49:642-647)
\end{abstract}

Keywords: Chlamydia trachomatis, heat shock protein, ELISA, antibody.

Genito-urinary

Medicine and

Communicable

Diseases,

Jefferiss Research

Trust Laboratories,

Imperial College

School of Medicine at

St Mary's,

London W2 1NY

P J Horner

$\mathrm{MAli}$

J $N$ Weber

M O McClure

The MRC Sexually

Transmitted Diseases

Research Group

P J Horner

D Taylor-Robinson

Murex Diagnostics

Ltd., Temple Hill,

Deptford, Kent

DA1 5LR

D Parker

Correspondence to

Dr P J Horner,

Department of

Genito-urinary Medicine

Bristol Royal Infirmary,

Bristol BS2 8HW.

Accepted for publication

7 May 1996
Chlamydia trachomatis is a major sexually transmitted micro-organism, leading to genital and ocular disease in men, women and infants. Two biovars of $C$ trachomatis are pathogenic in humans, the trachoma biovar, a pathogen of mucous membranes, and the lymphogranuloma venereum (LGV) biovar. The LGV biovar is much more invasive and causes systemic infections. Serovars A-C cause trachoma; serovars D-K primarily affect the genital tract where they cause urethritis, epididymitis, cervicitis, endometritis, and salpingitis, infection in women often being asymptomatic. Ocular infection with these serovars results in conjunctivitis, particularly in newborn infants of infected mothers.

Infection of fallopian tube mucosa by $C$ trachomatis in organ culture has little or no direct deleterious effect. ${ }^{1}$ In other words, the changes are insufficient to account for the damage that occurs in vivo. The pathogenesis of the inflammatory damage is, therefore, believed to involve components of the immune system. Much of the understanding of the immunopathogenesis of the $C$ trachomatis trachoma biovar has come from experimental infection of primates and smaller laboratory क animals. Studies of $C$ psittaci in guinea pigs ${ }^{2} \vec{\circ}$ and $C$ trachomatis in monkeys ${ }^{3}$ demonstrated that a detergent soluble extract of chlamydial elementary bodies induced conjunctival inflammation in immune, but not in naive animals. This inflammatory response is similar histologically to that produced by whole organisms and that seen in salpingitis in humans. Morrison et $a l^{45}$ showed that the detergent extract of $C$ psittaci contained a genus specific protein of $57 \mathrm{kDa}$ which belongs to the family of heat shock proteins (hsp60). This protein, the molecular sequence of which is known, has a considerable degree of homology with the mycobacteria $65 \mathrm{kDa}$ protein, Escherichia coli and human hsp60, ${ }^{4-7}$ and is thought to mediate the immunopathology that follows chlamydial infection. ${ }^{467}$

Heat shock proteins, popularly referred to as molecular chaperones, have essential roles in the synthesis, transport and folding of proteins. They are among the most conserved proteins in phylogeny with respect to both structure and function. Many hsps are essential for life and their synthesis increases in response to a variety of insults to ensure survival under stressful conditions. ${ }^{8}$ Most hsps have been grouped into families on the basis of their apparent molecular weight. The chlamydial hsp60 can be isolated from the outer membrane of elementary bodies and may participate in the assembly of the chlamydial cell wall.?

Wagar et $a l^{9}$ and Toye et $a l^{10}$ demonstrated that a serological response to chlamydial hsp60 was associated with the chronic sequelae of pelvic inflammatory disease in patients who had a classic immune response to chlamydial 2 infection. This suggests that the serological response to chlamydial hsp60 may be important in the immunopathogenesis of persistent inflammation of the genital tract in humans. To investigate this possibility further, we have developed an indirect ELISA for the hsp60 of $C$ trachomatis serovar E, the development and details of which are presented herein.

\section{Methods}

AMPLIFICATION OF CHLAMYDIAL HSP60 DNA BY PCR

A conserved region of the DNA sequence encoding the hsp60 gene for $C$ trachomatis serovar A was used to design primers for PCR for the amplification of the hsp60 gene from $C$ trachomatis serovar $\mathrm{E}$. The primer sequences were: (a) 5'> TCC CCC GGG ATA TGG 
TCG CTA AAA ACA TT <3' and (b) 5'> GAG CCC GGG ATT AAT AGT CCA TTC CTG CGC C $<3$ '.

$C$ trachomatis serovar $\mathrm{E}$, grown in $\mathrm{McC}$ oy cells, was purified on a sucrose gradient and DNA extracted using standard methods. ${ }^{11}$ The PCR reaction was carried out in a final volume of $50 \mu \mathrm{l}$ containing $5 \mu \mathrm{l} 10 \times$ buffer $(500 \mathrm{mM}$ $\mathrm{KCl}, 100 \mathrm{mM}$ Tris- $\mathrm{HCl}(\mathrm{pH} 8.0), 1 \mathrm{mg} / \mathrm{ml}$ gelatin, and $1 \%$ Triton X-100), $4 \mu \mathrm{l}$ of dNTPs $(1 \mathrm{mg} / \mathrm{ml}), 1.5 \mathrm{mM} \mathrm{MgCl}, 1 \mu \mathrm{l}$ of Taq polymerase, $1 \mu \mathrm{l}(100 \mathrm{ng})$ of oligonucleotide primers (a) and (b), and $200 \mathrm{ng}$ of genomic chlamydial DNA. The DNA was annealed at $60^{\circ} \mathrm{C}$ for 120 seconds, extended at $72^{\circ} \mathrm{C}$ for 150 seconds and denatured at $95^{\circ} \mathrm{C}$ for 150 seconds for 35 cycles using a thermal cycler (Perkin Elmer, UK), with an extension time of seven minutes in the final cycle.

SUBCLONING OF PCR AMPLIFIED PRODUCT

The PCR amplified DNA was purified on a $1 \%$ agarose gel and a band of the appropriate size was excised and isolated using the GeneClean (BIO101, UK) protocol. The DNA recovered was digested with the restriction enzyme Sma I and further purified using the GeneClean method. To construct a recombinant clone that contained the hsp60 protein, the prokaryotic expression vector pDEV-107 (Murex Diagnostics, Deptford, Kent, UK) (fig 1), which produces a $\beta$-galactosidase carboxyl terminal fusion protein, was digested with Sma I and purified on a $1 \%$ agarose gel, as described previously. The PCR product (10 ng) and expression vector pDEV-107 (5 ng) were blunt-end ligated and transformed with DH5a (Gibco BRL, Paisley, UK) competent $E$ coli cells using standard protocols. ${ }^{11}$ The transformed cells were plated onto $1.6 \%$ agar containing X-gal $(800 \mu \mathrm{g} / \mathrm{ml})$ and ampicillin $(100 \mu \mathrm{g} / \mathrm{ml})$ and recombinant clones isolated and characterised by restriction digestion of mini DNA preparations. ${ }^{11}$ The above procedure was also carried out with pDEV-107 alone.

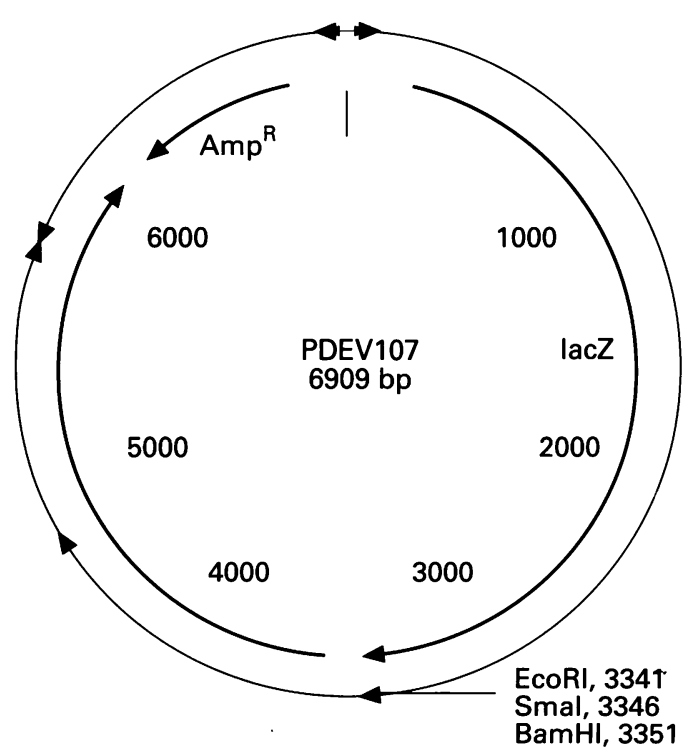

Figure 1 Restriction map of the pDEV-107 expression vector.
SOUTHERN BLOT ANALYSIS

After restriction enzyme digestion, the DNA was analysed by agarose gel electrophoresis and DNA from clones successfully transformed by pDEV-107 and containing the chlamydial PCR product was transferred to a Genescreen (Dupont, UK) membrane. This was probed with an oligonucleotide, the sequence of which (5' ATT TCT GCT AAT AAT GAT GCA GAA ATC 3') was located between the primer pairs and corresponded to a conserved region of the hsp 60 gene in both $C$ trachomatis serovar A and $C$ psittaci. When recombinant clones were identified, glycerol stocks were prepared: one containing chlamydial PCR product insert and one with $\mathrm{pDEV}-$ 107 alone.

EXPRESSION OF CHLAMYDIAL HSP 60

$\beta$-GALACTOSIDASE CARBOXY-TERMINAL FUSION PROTEIN AND $\beta$-GALACTOSIDASE

A $10 \mu \mathrm{l}$ volume of glycerol stock was added to $15 \mathrm{ml} \mathrm{LB}$ broth containing $100 \mu \mathrm{g} / \mathrm{ml}$ ampicillin and incubated overnight at $37^{\circ} \mathrm{C}$. This seeding culture was added to $300 \mathrm{ml} \mathrm{LB}$ broth containing $100 \mu \mathrm{g} / \mathrm{ml}$ ampicillin, incubated at $37^{\circ} \mathrm{C}$ for one hour and induced with $50 \mu \mathrm{g} / \mathrm{ml}$ IPTG for a further three and a half hours. After centrifugation at $10000 \times g$ for 20 minutes, the pellet was washed twice in TEN buffer (25 $\mathrm{mM}$ Tris $\mathrm{HCl}$ (pH 8.0), $1 \mathrm{mM}$ EDTA and 100 $\mathrm{mM} \mathrm{NaCl}$ ) and resuspended in $3.0 \mathrm{ml}$ TEN buffer per g $E$ coli in the presence of $2 \mu \mathrm{g} / \mathrm{ml}$ leupeptin, $2 \mu \mathrm{g} / \mathrm{ml}$ pepstatin, $2 \mu \mathrm{g} / \mathrm{ml} \mathrm{E} 64$, and $300 \mu \mathrm{g} / \mathrm{ml}$ phenyl methyl sulphonyl fluoride (PMSF). To this was added $20 \mathrm{mg} / \mathrm{ml}$ lysosyme and the mixture kept on ice for 90 minutes. Deoxycholic acid (3 mg per g $E$ coll) was then added with gentle agitation for 20 minutes before addition of $\mathrm{MgSO}_{4}$ (final concentration $10 \mathrm{mM}$ ) and incubated with DNase I (final concentration $100 \mu \mathrm{g} / \mathrm{ml}$ ) at $4^{\circ} \mathrm{C}$ overnight. This lysate was stored at $20^{\circ} \mathrm{C}$ in $500 \mu$ l aliquots.

SEMI-PURIFICATION OF HSP60 PROTEIN

An aliquot of the lysate was centrifuged at $13000 \times g$ and the pellet resuspended on ice for 10 minutes in $1 \mathrm{ml}$ TEN buffer containing protease inhibitors (leupeptin, pepstatin, E64, and PMSF) and $0.5 \%$ Triton X-100 (lysis buffer), then centrifuged at $13000 \times g$ for three minutes at $4^{\circ} \mathrm{C}$. The supernatant was discarded and the procedure repeated twice. The pellet was then washed three times with ice-cold TEN buffer containing protease inhibitors, but without detergent, washed in lysis buffer and then resuspended on ice for five minutes in lysis buffer without the protease inhibitors, but containing $4 \mathrm{M}$ urea. This preparation was centrifuged at $13000 \times g$ for one minute at $4^{\circ} \mathrm{C}$ and the supernatant discarded. This step was repeated and the pellet resuspended in $1 \mathrm{ml}$ lysis buffer containing $7 \mathrm{M}$ urea and kept on ice for 10 minutes. Following centrifugation at $13000 \times g$ for $10 \mathrm{~min}$ utes at $4^{\circ} \mathrm{C}$, the supernatant was diluted 1 in 1 in glycerol to a final dilution of 1 in 4 . This could be stored at $-70^{\circ} \mathrm{C}$. 
For all absorption experiments, using $E$ coli containing $\beta$-galactosidase, the pellet mentioned earlier was washed three times and resuspended in phosphate buffered saline (PBS) following the washes in TEN buffer containing protease inhibitors, but no detergent.

CHARACTERISATION OF EXPRESSED RECOMBINANT PROTEIN

Samples were solubilised in sample buffer (62.5 mM Tris- $\mathrm{HCl}$ (pH 6.8) containing $10 \%$ SDS, 5\% $\beta$-mercaptoethanol, $10 \mathrm{mM}$ EDTA, $10 \%$ glycerol, and $0.5 \%$ bromophenol blue) and subjected to $7.5 \%$ polyacrylamide gel electrophoresis (SDS-PAGE). ${ }^{1213}$ Two identical gels were prepared, one of which was stained for protein visualisation with Coomassie blue and the other transferred to a nitrocellulose membrane (VDF-Immobilon/Millipore, UK). After transfer, the membrane was blocked with blocking solution (PBS containing $10 \%$ lamb serum (LS; Gibco) and 5\% non-fat milk powder; PBSB) for two hours and washed three times with PBS containing $0.1 \%$ Tween 20 (PBST). A mycobacterial hsp60 monoclonal antibody, ML-30, which recognises the chlamydial, but not the $E$ coli hsp60 antigen, was diluted 1 in 400 in blocking solution $(0.1 \%$ Tween 20 and $5 \% E$ coli lysate containing pDEV-107) and incubated with the membrane for one hour at $37^{\circ} \mathrm{C}$. The membrane was then washed three times with PBST and incubated with the second antibody (goat anti-mouse IgG conjugated to peroxidase; Sigma, Poole, Dorset, UK) at a dilution of 1 in 500 , and incubated with the membrane which was then washed, as described. Immunostaining was visualised following addition of DAB (3'3-diaminobenzidinetetrahydrochloride) substrate $(6 \mathrm{mg} / \mathrm{ml}$ in $50 \mathrm{mM}$ Tris- $\mathrm{HCl}$ (pH 7.5) and $10 \mu \mathrm{l} 30 \%$ hydrogen peroxide).

\section{ENZYME LINKED IMMUNOSORBENT ASSAY}

The solid phase (flat bottomed microtitre plates; Nunc, Denmark) was pre-coated with $100 \mu \mathrm{l}$ of a monoclonal antibody directed against $\beta$-galactosidase, BG-79 (Murex Diagnostics), at $7.5 \mu \mathrm{g} / \mathrm{ml}$ in PBS, $0.1 \% \mathrm{NaN}_{3}$ and incubated overnight at room temperature. The plates were washed four times in PBST and blocked with $200 \mu \mathrm{l}$ PBSB and $0.1 \% \mathrm{NaN}_{3}$ for two hours at room temperature, then washed three times in PBST. The antigens, chlamydial hsp60 $\beta$-galactosidase carboxyl terminal fusion protein and $\beta$-galactosidase, were captured onto the solid phase at a dilution of 1 in 160 in lysis buffer with $0.4 \mathrm{M}$ urea, and incubated overnight at room temperature. The solid phase was washed four times with PBST and blocked, as before, with PBSB and then washed three more times in the same buffer. Serum samples were diluted 1 in 100 in serum diluent, namely PBSB plus $2.5 \% E$ coli lysate containig $\mathrm{pDEV}-107$ to remove antibodies directed against $E$ coli and $\beta$-galactosidase, and $100 \mu \mathrm{l}$ was added to each of the captured antigens on the solid phase. This was incubated for one hour at $37^{\circ} \mathrm{C}$. After six washes in PBST, $100 \mu$ goat anti-human peroxidase conjugate, at a dilution of 1 in 3000 in PBSB, was added to each well and incubated and washed, as above. To each well, $100 \mu \mathrm{l}$ OPD $(1,2-$ phenylenediamine; Dako, High Wycombe, UK) hydrogen peroxide substrate was added. The reaction was developed in the dark for 20 minutes and stopped with $100 \mu \mathrm{l}$ of $1 \mathrm{M}$ $\mathrm{H}_{2} \mathrm{SO}_{4}$. Samples were read spectrophotometrically at $492 \mathrm{~nm}$.

SERUM SAMPLES USED AND CALCULATION OF THE ELISA CUT-OFF VALUE

The ELISA cut-off value, below which any serum sample assayed was considered to be hsp60 antibody negative, was calculated from के assaying 148 serum samples taken from 93 subjects known to be antibody negative to $C$ 을 trachomatis or $C$ pneumoniae by micro- $\vec{\omega}$ immunofluorescence (MIF). ${ }^{14}$ The cut-off ${ }^{\circ}$ value for the assay was calculated from these ? samples as the mean (corrected) optical te density (OD) +3 SD. In addition, serum samples from patients with acute chlamydial urethritis, confirmed by direct fluoresecent 0 antibody testing, who had antibody directed against $C$ trachomatis measured by MIF were used as positive controls.

\section{Results}

MOLECULAR AND BIOCHEMICAL

CHARACTERISATION OF RECOMBINANT PROTEIN

Subcloning of the chlamydial hps60 gene into $E$ coli was confirmed by Southern blotting (fig $2)$. Both the chlamydial hsp60 PCR product and the fragment subcloned into the pDEV107 expression vector and transformed into $E$ coli hybridised readily with the molecular probe.

SDS-PAGE of the recombinant fusion protein indicated the expected molecular weight of approximately $175 \mathrm{kD}$ and western blot analysis with the ML-30 monoclonal antibody indicated specific recognition (fig 3 ).

EVALUATION OF THE ELISA

Recombinant antigen captured on ELISA plates by the anti- $\beta$-galactosidase monoclonal antibody, BG-79, constituted the basis of the $C$ trachomatis ELISA. Absorbance values (OD

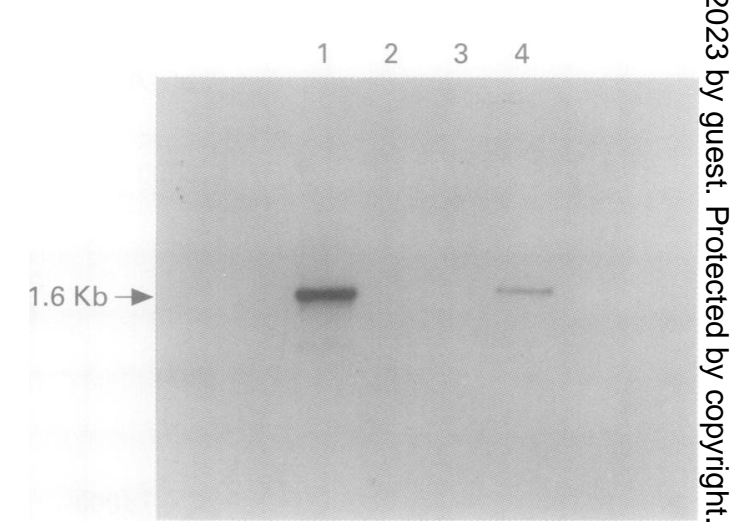

Figure 2 Southern blot using a conserved sequence common to hsp 60 of $\mathrm{C}$ trachomatis and $\mathrm{C}$ psittaci as a probe (see text), showing hybridisation of the probe with hsp60 PCR amplified DNA. Lane 1, PCR amplified DNA; lane 2, DNA amplified from uninfected McCoy cells; lane 3, water control; lane 4, PCR product in pDEV-107 expression vector. Non-equivalent amounts were loaded onto the gel. 
readings) due to any reaction of the 148 chlamydia antibody negative serum samples with $\beta$-galactosidase were in each case subtracted from the OD obtained when serum was

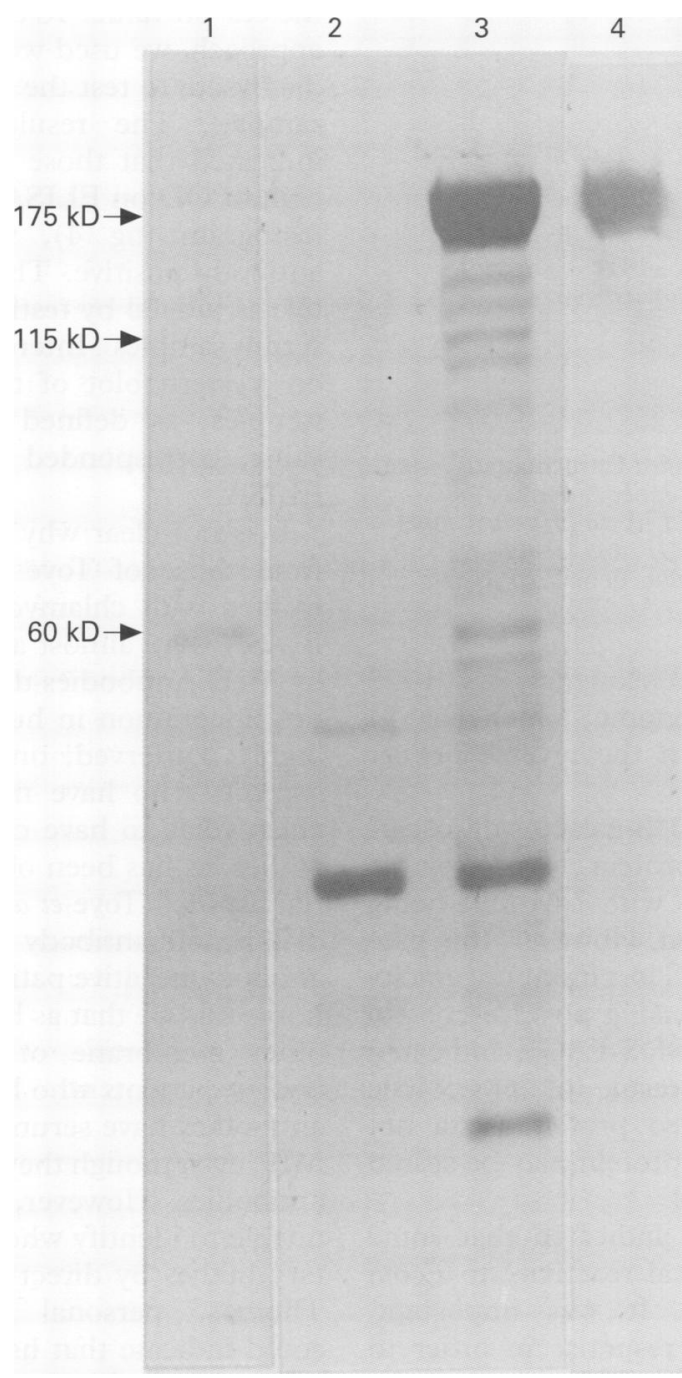

Figure 3 Western blot of recombinant hsp60 protein using $M L-30$. Lane 1, sucrose gradient purified $C$ trachomatis fractionated from $M c C$ Cy cells; lane 2, E coli expressing Bgalactosidase; lane $3, E$ coli lysate containing hsp 60 $\beta$-galactosidase fusion protein (and breakdown products); lane 4, purified hsp $60 \beta$-galactosidase fusion protein extracted in $7 M$ urea as described in the text.

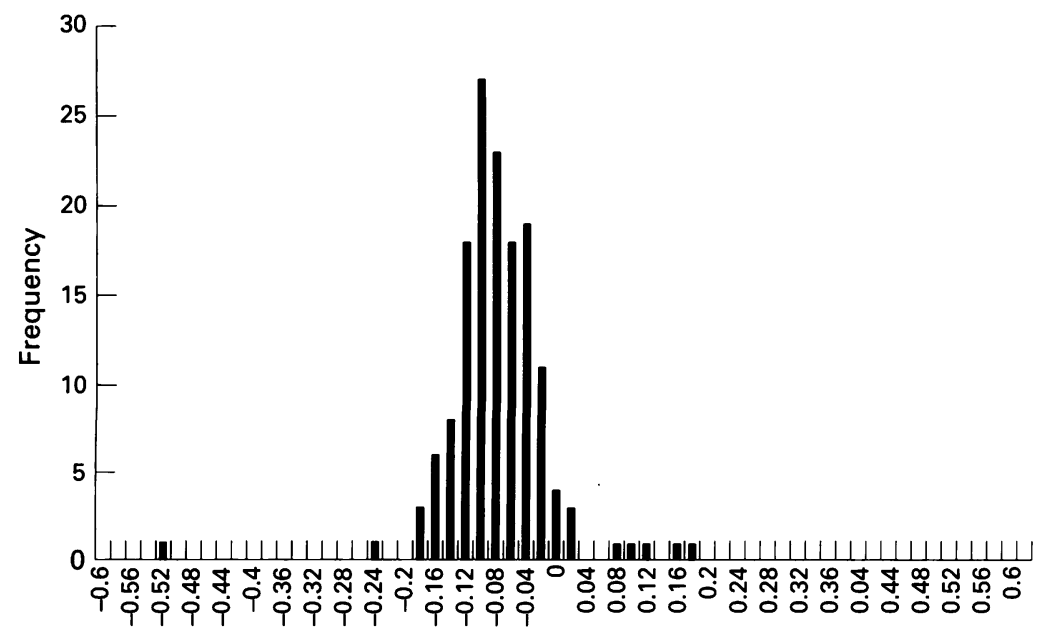

Optical density

Figure 4 Histogram showing (corrected) $O D$ at $492 \mathrm{~nm}$ for $C$ trachomatis and $C$ pneumoniae antibody negative control serum samples. incubated with the chlamydial hsp60 fusion protein. The results are shown in fig 4 .

The ELISA cut-off value was calculated from these serum samples. Using this, three positive control serum samples were identified from those patients with acute chlamydial urethritis, having OD values higher than the cut-off value.

The specificity of the assay was confirmed by western blot analysis using lysates of $C$ trachomatis and uninfected McCoy cells as sources of antigen. Lanes 1 and 13 in fig 5 confirm a band of $60 \mathrm{kD}$ when monoclonal antibody ML-30 is used. This identified the chlamydial hsp60 as the upper band of a protein doublet. The antibody status of the three positve control serum samples was positive by western blotting (fig 5, lanes 10-12). Of the 148 antibody negative serum samples, 15 (including the group of five outliers with the highest OD values in fig 4) were also subjected to western blotting. The five samples lying outside the main group distribution, with the highest $O D$ values, turned out to be seropositive by western blotting. (Four of these are shown in fig 5, lanes 6-9.) The remaining 10, four of which are shown in fig 5 , were confirmed as being seronegative (lanes $2-5$ ). The cut-off value, therefore, was amended by excluding the five samples that were positive for hsp60, by western blotting, from the 148 chlamydia antibody negative serum samples, as described previously.

\section{Discussion}

We have subcloned the hsp 60 gene from $C$ trachomatis serovar $\mathrm{E}$ into $E$ coli and expressed it as a $\beta$-galactosidase carboxyl terminal fusion protein. This was used to develop a sensitive and relatively specific ELISA for the detection of antibodies directed against chlamydial hsp60.

The hsp60 genome is highly conserved. From the nucleotide sequences of $C$ psittaci and $C$ trachomatis hsp60 more than $80 \%$ homology has been demonstrated. ${ }^{5}$ We assumed, therefore, that the homology between $C$ trachomatis serovars would be such that PCR primers designed for $C$ trachomatis serovar A would subclone the hsp60 gene from $C$ trachomatis serovar E. This was, indeed, the case. In addition, a Southern blot probe was derived from a DNA sequence homologous to $C$ psittaci and $C$ trachomatis. The same principle was used to determine whether the subcloned chlamydial hsp60 gene was inserted into pDEV-107 in the correct orientation following blunt-end ligation. The hsp60 gene of $C$ trachomatis serovar A has one Bam $\mathrm{H} 1$ restriction site at position 133. The pDEV-107 expression vector has a Bam $\mathrm{H} 1$ restriction site at the $3^{\prime}$ end of the cloning site. Thus, the correct orientation was confirmed by restriction enzyme digestion with Bam $\mathrm{H} 1$. The probe used for the Southern blot analysis recognised both the PCR product and the insert subcloned into pDEV-107 from the successfully transformed $E$ coli. Two PCR products hybridised with the molecular probe. The lower molecular weight product of approximately 


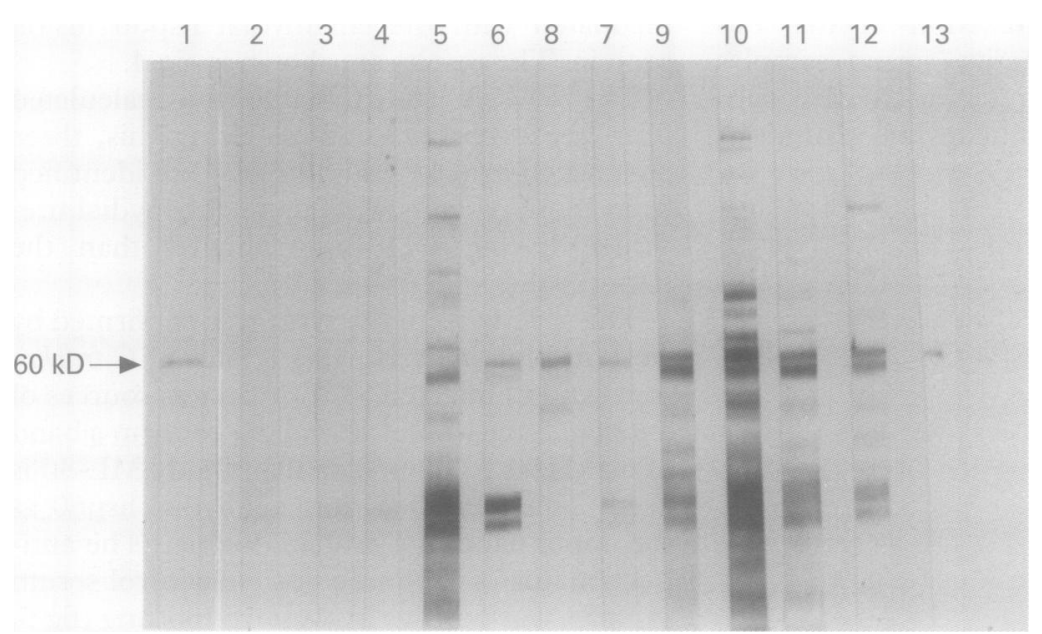

Figure 5 Lanes 1 and 13, western blot of sucrose gradient purified C trachomatis lysate using $M L-30$; lanes 10-12, patient serum samples known to be antibody positive for $\mathrm{C}$ trachomatis by MIF, which had OD values higher than the ELISA cut-off values; lanes 2-5, patient serum samples known to be antibody negative by MIF; and lanes 6-9, antibody negative serum samples which gave the highest OD values in the ELISA (see text). chlamydia negative on the basis of MIF serology were also almost invariably negative when tested for chlamydial hsp 60 antibody by ELISA. We therefore used this criterion to $c$ select our negative controls for calculation of $\Omega$ the cut-off value. To confirm the validity of this approach, we used western blots with chlamydial lysate to test the "negative" control serum $\overline{\mathrm{\sigma}}$ samples. The result of the western blot indicated that those serum samples with the highest OD on ELISA (distinct outliers on the $\overline{0}$ histogram, fig 4), were chlamydial hsp60 antibody positive. The remainder were nega- $\frac{\bar{\omega}}{\bar{D}}$ tive as judged by testing 10 randomly selected $\stackrel{\square}{\varrho}$ serum samples . Interestingly, the band density के on western blot of the three positive serum $\vec{\circ}$ samples, as defined by the ELISA cut-off value, corresponded to the relative $\mathrm{OD}$ on ELISA.

It is not clear why our results should differ ? from those of Toye et al, ${ }^{10}$ who found that $\overrightarrow{0}$ women with chlamydial hsp60 antibodies by ELISA were almost always chlamydia positive by MIF. Antibodies directed against hsp60 are 응 not uncommon in humans. As this protein is highly conserved, one would expect to find subjects who have never been infected with chlamydiae to have cross-reactive hsp60 anti- $\stackrel{\text { क }}{\rightarrow}$ bodies, as has been observed with mycobacte- $\vec{\theta}$ rial hsp65. ${ }^{15}$ Toye et $a l^{10}$ only detected chlamydial hsp60 antibody in 1 of 160 chlamydia antibody negative patients. A possible explanation could be that as hsp60 is expressed on the outer membrane of chlamydial elementary bodies, patients who have cross-reactive hsp60 antibodies have serum that reacts positively in $\overrightarrow{\vec{B}}$ MIF, even though they have no anti-chlamydial antibodies. However, using ML-30 we were unable to identify whole $C$ trachomatis elementary bodies by direct immunofluorescence (B Thomas, personal communication). This could indicate that hsp60 is not immunologically recognisable on the elementary bodies or 8 it may associate only with the ML-30 epitope. Our data suggest that the chlamydial hsp60 is 윽 not recognised by anti-hsp60 antibodies on chlamydial elementary bodies. Another explanation for the difference in findings between $N$ ourselves and Toye $e t a l^{10}$ is that the glucuronidase hsp60 fusion protein has a different $\tilde{N}$ immunogenic profile from the $\beta$-galactosidase $\omega$ hsp60 fusion protein we used in the ELISA. In support of this is our observation that the immunogenicity of our fusion protein varied $\$$ widely depending on how it was solubilised and stored. An alternative explanation may be that Toye $e t a l^{10}$ routinely used serum samples diluted 1 in 500 and it may be that at this dilu- $\frac{D}{D}$ tion their assay was insufficiently sensitive to detect cross-reactive anti-chlamydial hsp60 antibodies.

we used this background OD value to calculate the threshold OD value for the ELISA, the cut-off value was such that the assay was insufficiently sensitive to detect two of the three positive controls. A subtraction assay, therefore, was used to remove the high background. As can be seen from fig 4, this gave a surprisingly unambiguous normal distribution for the negative results. Previous work from Toye et $a l^{10}$ indicated that samples that were
The authors thank Dr Brenda Thomas for providing the The authors thank Dr Brenda Thomas for providing the
chlamydia negative and positive control sera, Professor J Ivanyi,
Royal Postgraduate Medical School, London, for his gift of Royal Postgraduate Medical School, London, for his gift of
monoclonal ML-30 and Murex Diagnostics for pDEV-107 and monoclonal ML- 30 and Murex D
the BG-79 monoclonal antibody.

1 Hutchinson GR, Taylor-Robinson D, Dourmashkin RR. Growth and effect of chlamydiae in human bovine oviduct organ cultures. Br f Ven Dis 1979;55:194-202.

2 Watkins NG, Hadlow WJ, Moos AB, Caldwell HD. Ocular delayed hypersensitivity: A pathogenic mechanism of 
chlamydial conjunctivitis in guinea pigs. Proc Natl Acad $S_{c i}$ USA 1986;83:7480-4.

3 Taylor HR, Johnson SL, Schachter J, Caldwell HD, Prendergast RA. Pathogenesis of trachoma: The stimulus for inflammation. F Immunol 1987;138:3023-7.

4 Morrison RP, Belland RJ, Lyng K, Caldwell HD. Chlamydial disease pathogenesis: The $57-\mathrm{kD}$ chlamydial hypersensitivity antigen is a stress response protein. $\mathcal{F} \operatorname{Exp} \mathrm{Med}$ 1989;170:1271-83.

5 Morrison RP, Su H, Lyng K, Yuan Y. The Chlamydia trachomatis operon is homologous to the groE stress trachomatis operon is homologous to the groE stress
response operon of Escherichia coli. Infect Immun response operon

6 Cerrone MC, Ma JJ, Stephens RS. Cloning and sequence of the gene for the heat shock protein 60 from Chlamydia trachomatis and immunological reactivity of the protein. Infect Immun 1991;59:79-90.

7 Bavoil P, Stephens RS, Falkow S. A soluble 60 kiloDalton antigen of Chlamydia spp. is a homologue of Escherichia coli Groel. Mol Microbiol 1990;4:461-9.

8 Craig EA. Chaperones: helpers along the pathways to protein folding. Science 1993;260:1902-4.

9 Wagar EA, Schachter J, Bavoil P, Stephens RS. Differential human serological response to two 60,000 molecular weight Chlamydia trachomatis antigens. $\mathcal{f}$ Infect Dis 1990; 162:922-7.

10 Toye B, Laferriere C, Claman P, Jessamine P, Peeling R. Association between antibody to the chlamydial heatshock protein and tubal infertility. F Infect Dis 1993; 168: $1236-40$.

11 Sambrook J, Fritsch EF, Maniatis T. Molecular cloning: $A$ laboratory manual. 2nd edn. Cold Spring Harbor: Cold Spring Harbor Laboratory Press, 1989.

12 Towbin J, Staehlin T, Gordon J. Electrophoretic transfer of proteins from polyacrylamide gels to nitrocellulose sheets: proteins from polyacrylamide gels to nitrocellulose sheets: Procedures and

13 Bjerrum OJ, Schafer-Nielsen C Buffer systems and transfer parameters for semi-dry electroblotting with a horizontal apparatus. In: Dunn MJ ed. Electrophoresis '86. Weinheim, Germany: VCH Verlag, 1986:315-27.

14 Thomas BJ, Reeve P, Oriel JD. Simplified serological test for antibodies to Chlamydia trachomatis. $\mathcal{f}$ Clin Microbiol 1976;4:6-10.

15 Jackett PS, Bothamley GH, Batra HV, Mistry A, Young DB, Ivanyi J. Specificity of antibodies to immunodominant mycobacterial antigens in pulmonary tuberculosis. $f$ Clin Microbiol 1988;26:2313-8. 